\title{
PENERAPAN KERANGKA RANCANGAN TANDUR DALAM MODEL PEMBELAJARAN SNOWBALL THROWING UNTUK MENINGKATKAN HASIL BELAJAR IPA SMPN 03 CANDIPURO LUMAJANG
}

\author{
Henia Wati ${ }^{1}$, Abdulkadir Rahardjanto ${ }^{1}$, Atok Miftachul Hudha ${ }^{1}$ \\ ${ }^{1}$ Program Studi Pendidikan Biologi FKIP Universtias Muhammadiyah Malang, \\ e-mail: rahardjanto@gmail.com
}

\begin{abstract}
ABSTRAK
Pembelajaran Snowball Throwing merupakan pembelajaran kooperatif yang bekerja secara berkelompok secara kolaboratif yang penerapannya membuat sebuah pertanyaan yang dituliskan dikertas kemudian diremas menyerupai bentuk bola salju lalu dilemparkan kepada siswa lain dan siswa lain yang mendapatkan bola kertas dibuka dan menjawab perrtanyaan. Adanya kerjasama secara kooperatif ini mendorong siswa untuk lebih aktif dalam kegiatan pembelajaran, sedangkan guru hanya bertindak sebagai fasilitator yang bertugas mengorganisasikan materi, mengorganisasikan siswa dan menyiapkan bahan-bahan yang diperlukan dalam kegiatan pembelajaran. Hasil observasi dan wawancara dengan guru mata pelajaran Biologi kelas VIII-B di SMPN 03 Candipuro Lumajang, menunjukkan bahwa pembelajaran Biologi yang diterapkan selama ini masih berorientasi pada guru (teacher centered) dan selalu dilakukan secara konvensional, sehingga siswa mayoritas tidak mengerti bagaimana hubungan antara fakta yang ada dengan kehidupan sehari-hari. Hal ini karena siswa dalam mencapai pengetahuan atau konsep materi pelajaran masih belum terlaksana. Selain itu, nilai hasil belajar siswa kelas VIII-B mayoritas di bawah KKM yang telah ditentukan yaitu 70. Penelitian ini bertujuan untuk mengetahui penerapan model pembelajaran Snowball Throwing yang didalamnya terdapat kerangka rancangan TANDUR dalam meningkatkan hasil belajar IPA SMPN 03 Candipuro Lumajang pada materi metamorfosis dan metagenesis. Jenis penelitian yang dilakukan adalah penelitian tindakan kelas (Classroom Action Reseacrh) dengan menggunakan prosedur kerja yang dipandang sebagai siklus spiral yang meliputi kegiatan perencanaan, tindakan, observasi, dan refleksi. Hasil penelitian menunjukkan adanya peningkatan hasil belajar siswa kelas VIII-B SMPN 03 Candipuro Lumajang dari siklus I ke siklus II. Hasil belajar klasikal pada siklus II lebih baik dibandingkan siklus I, hal ini ditunjukkan dari hasil analisa ketuntasan hasil belajar klasikal yang mengalami peningkatan dari 75\% pada siklus I menjadi 95,83\% pada siklus II yang artinya terjadi peningkatan sebesar 20,83\%.
\end{abstract}

Kata Kunci : Hasil Belajar, Snowball Throwing, Kerangka Rancangan Tandur

Pendidikan merupakan investasi jangka panjang yang memerlukan suatu usaha dan proses yang cukup besar, hal ini sudah diakui oleh semua orang demi kelangsungan masa depan suatu bangsa. Pendidikan merupakan proses untuk mewujudkan perubahan berbagai tingkah laku yang baik meliputi ranah afektif, kognitif, dan psikomotorik (Subiyanto,1998; Dimyati dan Mudjiono, 2009). Sebagaimana yang tercantum dalam Bab I Undang-undang Nomer 20 Tahun 2003, tentang Sistem Pendidikan Nasional dinyatakan bahwa pendidikan merupakan suatu usaha sadar dan terencana dalam mewujudkan suasana belajar dan proses pembelajaran agar peserta didik secara aktif dapat mengembangkan potensi dirinya untuk memiliki kekuatan spiritual keagamaan, pengendalian diri, kepribadian, kecerdasan, akhlak mulia serta keterampilan yang diperlukan dirinya, masyarakat, bangsa dan negara.

Salah satu kelemahan pendidikan saat ini adalah pada proses pembelajaran yang diterapkan di dalam kelas. Siswa kurang dilatih untuk memiliki kecakapan berfikir. Siswa banyak diarahkan untuk menguasai materi pada sebagian ranah kognitif yaitu mengahafal dan mengingat semua informasi (Arikunto, 2006), termasuk mata pelajaran biologi yang 
banyak memiliki konsep. Sedangkan kemampuan siswa pada ranah sebagian ranah kognitif, afektif dan psikomotorik belum optimal terasah. Oleh karena itu, kecakapan berfikir khususnya kemampuan dalam memecahkan masalah perlu dikembangkan. Salah satu usaha untuk meningkatkan kualitas pendidikan dari segi pelaksanaan secara operasional adalah terwujud dalam kegiatan belajar mengajar.

Dalam kegiatan belajar mengajar, model pembelajaran merupakan faktor yang sangat penting untuk menentukan keberhasilan pencapaian tujuan pembelajaran (Winataputra, 2001). Penentuan model pembelajaran yang tepat oleh guru sangat diperlukan agar sesuai dengan materi pelajaran yang akan diajarkan kepada siswa. Kenyataan yang banyak dijumpai di kelas suatu sekolah selama ini adalah pembelajaran berpusat pada guru (teacher centered learning) yang menempatkan guru sebagai pemberi pengetahuan bagi siswa, dan cara penyampaian pengetahuannya cenderung masih didominasi dengan metode ceramah, serta masih mengutamakan buku paket sebagai salah satu sumber belajar terpenting. Penggunaan metode ceramah yang dominan dan kurang maksimalnya proses pembelajaran tersebut menyebabkan partisipasi rendah, kemajuan siswa, perhatian dan minat siswa tidak dapat dipantau. Hal ini didukung dengan hasil observasi yang dilaksanakan pada tanggal 5 september 2012 terhadap proses belajar mengajar biologi kelas VIII-B SMPN O3 Candipuro Lumajang melalui wawancara dengan salah satu guru mata pelajaran biologi, diketahui bahwa nilai hasil belajar siswa masih rendah. Peserta didik hanya duduk tenang dibangku, mendengarkan serta menyerap dan menyimpan informasi, kemudian mencatat dan mengerjakan soal latihan yang diberikan guru. Sebagain besar siswa kurang aktif bertanya maupun berpendapat untuk menyampaikan gagasannya. Kondisi seperti ini akan menyebabkan peserta didik tidak konsentrasi dalam pembelajaran biologi yang disampaikan guru, mengantuk, dan berbicara dengan teman sebangku.

Berdasarkan hal tersebut, maka model pembelajaran Snowball Throwing dan kerangka rancangan TANDUR merupakan alternatif model pembelajaran yang dikembangkan untuk meningkatkan hasil belajar siswa. Tujuan utama dari Snowball Throwing dan kerangka rancangan TANDUR adalah pembelajaran untuk mendapatkan pengetahuan, sehingga siswa terlatih untuk memecahkan masalah dalam kehidupan sehari-hari.

Snowball Throwing merupakan salah satu model pembelajaran (Herdian, 2009) kooperatif learning yang terdiri atas tim-tim belajar yang beranggotakan 4-6 peserta didik yang heterogen (Trianto,2007). Model pembelajaran ini, dengan kelebihannya (Rahayu, 2009), akan membawa dampak terhadap hasil belajar yang bermakna bagi peserta didik jika penerapannya dikaitkan dengan kerangka rancangan yang berorientasi pada pembelajaran kontekstual. Kerangka rancangan TANDUR terdapat dalam metode Quantum yang menganut azas "bawalah dunia mereka kedunia kita dan antarkan dunia kita kedunia mereka", maksudnya seorang guru harus mampu membuat jembatan yang menghubungkan materi yang diajarkan dengan kehidupan peserta didik (DePorter (2008). Salah satu penelitian terdahulu yang dilakukan oleh Siti Komariyah Ulfa terhadap prestasi belajar IPS menunjukkan hasil yang positif terjadi peningkatan hasil belajar dari siklus I ke siklus II. Melalui penerapan model pembelajaran Snowball Throwing yang didalamnya terdapat kerangka rancangan TANDUR yang bertujuan agar peserta didik lebih mudah memahami suatu materi pelajaran, senang dalam mengikuti kegiatan belajar mengajar, mampu menemukan konsep materi, serta mudah mengingat konsep materi yang diajarkan.

Salah satu penelitian terdahulu yang dilakukan oleh Trimo dan Rusatiningsih (2008) mengenai kolaborasi metode Quantum Teaching dan Snowball 
Throwing terhadap peningkatan hasil belajar IPS menunjukkan hasil positif yaitu terjadi peningkatan hasil belajar peserta didik dengan prosentase ketuntasan belajar klasikal pada siklus I sebesar 81,90 \% dan pada siklus II sebesar $87,62 \%$.

\section{METODE}

Jenis penelitian ini merupakan penelitian tindakan kelas (PTK) (Chotimah, dkk., 2009) yang dilakukan secara bersiklus. Penelitian tindakan kelas dilaksanakan dengan mengikuti modifikasi siklus model Kemmis dan Taggart (2009), dengan menggunakan prosedur kerja yang dipandang sebagai siklus spiral yang mencakup kegiatan perencanaan, tindakan, observasi, refleksi atau evaluasi. Jumlah siklus dalam penelitian ini sangat tergantung pada masalah yang akan diselesaikan. Siklus I dalam penelitian ini tidak akan dilanjutkan ke siklus II, apabila permasalahan didalam siklus I sudah dapat mencapai tujuan. Indikator tercapainya tujuan adalah apabila telah diperoleh peningkatan kemampuan kerja ilmiah dan hasil belajar peserta didik pada materi metamorfosis dan metagenesis. Peran peneliti dalam Penelitian Tindakan Kelas (PTK) ini adalah sebagai pengajar sekaligus pengumpul, penganalisis data, dan sebagai penyusun laporan penelitian.

Penelitian ini dilaksanakan di SMPN 03 Candipuro Lumajang dimulai dari tanggal 18 September sampai dengan 25 September 2012. Subyek dalam penelitian ini adalah peserta didik kelas XIII B SMPN 03 Candipuro Lumajang Tahun Ajaran 2012/2013, yang berjumlah 24 peserta didik.

Penelitian ini terdiri dari 1 siklus, akan tetapi apabila pada siklus pertama belum berhasil, maka akan dilakukan siklus yang selanjutnya. Tiap siklus terdiri dari beberapa tahapan: 1) Perencanaan (planning). Perencanaan tindakan berdasarkan pada identifikasi masalah yang dilakukan pada pra-PTK. Rencana yang akan dilakukan pada rencana tindakan adalah menyiapkan silabus, RPP, Hand Out materi, LKPD, soal dan rubrik tes formatif, serta media pembelajaran. 2) Tindakan (acting). Pada setiap pertemuan tindakan yang dilakukan sama. Pada tahap ini yaitu melaksanakan kegiatan belajar mengajar sesuai dengan RPP yaitu melaksanakan pembelajaran biologi dengan penerapan kerangka rancangan TANDUR dalam model pembelajaran Snowball Throwing. 3) Observasi (observing). Kegiatan observasi dilakukan bersamaan dengan pelaksanaan tahap tindakan oleh dua orang observer. Persyaratan observer adalah orang yang telah diberikan pengetahuan tentang penerapan kerangka rancangan TANDUR dalam model pembelajaran Snowball Throwing. Kegiatan yang dilakukan observer pada tahap ini adalah mengamati proses belajar mengajar yang berlangsung di kelas. Adapun data yang diamati yaitu keterlaksanaan penerapan kerangka rancangan TANDUR dalam Model Pembelajaran Snowball Throwing yang meliputi aktivitas guru dalam mengajar dan aktivitas peserta didik dalam mengikuti pelajaran. 4) Refleksi. Data yang direfleksikan adalah hasil observasi dan nilai tes hasil belajar sebagai bahan pertimbangan siklus berikutnya. Untuk meneruskan ke siklus berikutnya. Dua kriteria yang digunakan sebagai penentu siklus berikutnya adalah: 1) keterlaksanaan sintaks belum optimal berdasarkan hasil observasi, 2) apabila ketuntasan individu belum mencapai KKM yaitu 70 .

Data hasil belajar siswa pada materi metamorfosis dan metagenesis diperoleh dari pemberian tes formatif yang dilakukan di setiap akhir siklus berupa post test. Sedangkan data tentang keterlaksanaan penerapan kerangka rancangan TANDUR dalam Model Snowball Throwing. Sumber datanya diperoleh dari aktivitas mengajar guru dan aktivitas peserta didik selama mengikuti pelajaran. Analisis proses pembelajaran 
dilakukan dengan teknik deskriptif kualitatif (Nazir, 2003) dari lembar observasi aktivitas guru dan peserta didik terhadap keterlaksanaannya penerapan kerangka rancangan TANDUR dalam model pembelajaran Snowball Throwing, serta catatan lapang yang telah diberikan kepada observer pada saat proses pembelajaran berlangsung.

Data yang berupa hasil belajar berupa skor per per butir soal kemudian diubah menjadi nilai dengan menggunakan acuan kriterium (menggunakan PAP), artinya penentuan nilai seorang peserta didik dilakukan dengan jalan membandingkan skor mentah hasil tes dengan skor maksimum idealnya dan akan digunakan rumus sebagai berikut.

1) Ketuntasan Individu.

$$
K B=\frac{T}{T t} \times 100 \%
$$

Keterangan :

$\mathrm{KB}=$ ketuntasan belajar

$\mathrm{T}=$ Jumlah skor yang diperoleh peserta didik

$\mathrm{Tt}=$ Jumlah skor total

Ketuntasan individu dikatakan tuntas apabila mencapai mencapai ketuntasan belajar jika telah mencapai nilai $>70$ (Sudjono,2008).

2) Ketuntasan klasikal.

$$
K S=\frac{n}{N} \times 100 \%
$$

Keterangan :

$\mathrm{KS}=$ ketuntasan belajar peserta didik

$\mathrm{n}=$ jumlah peserta didik yang belajar tuntas

$\mathrm{N}=$ jumlah seluruh peserta didik

(Sudjono, 2008)

Pembelajaran dikatakan berhasil apabila $85 \%$ dari jumlah siswa dikelas memiliki ketuntasan individu SKM yang ditetapkan untuk peserta didik SMPN 03 Candipuro Lumajang adalah $\geq 70$. Kriteria ketuntasan klasikal dapat dilihat pada Tabel 1.
Tabel 1. Kriteria Ketuntasan Belajar Klasikal

\begin{tabular}{cc}
\hline $\begin{array}{c}\text { Interval Nilai Ketuntasan } \\
\text { Belajar }\end{array}$ & Kriteria \\
\hline $85-100 \%$ & Sangat Baik \\
$70-84 \%$ & Baik \\
$55-69 \%$ & Cukup \\
$40-54 \%$ & Kurang \\
$0-39 \%$ & Sangat Kurang \\
\hline
\end{tabular}

HASIL

Penerapan kerangka rancangan TANDUR dalam model Snowball Throwing yang telah dilakukan baik pada siklus I maupun siklus II dan ketercapaian indikator penelitian dapat digambarkan pada hasil belajar pada tiap siklus. Pada tahap perencanaan guru menyiapkan perangkat-perangkat pembelajaran seperti menyusun silabus dan RPP sesuai dengan indikator ruang lingkup materi pembelajaran yang akan disampaikan kepada peserta didik, menyusun Lembar Kegiatan Peserta Didik (LKPD), mempersiapkan kisi-kisi soal tes, mempersiapkan soal tes sebagai alat ukur hasil belajar peserta didik dan rubrik penilainnya, mempersiapkan lembar observasi keterlaksanaan sintaks, lembar penilaian aktivitas guru dan lembar penilaian aktivitas peserta didik, dan mempersiapkan kamera untuk mendokumentasikan pelaksanaan penerapan kerangka rancangan TANDUR dalam model pembelajaran Snowball Throwing.

Pelaksanaan penelitian ini dilakukan oleh peneliti yang bertindak sebagai guru pengajar dan dibantu 2 orang observer (Dita dan Enggar) dan satu orang dokumenter untuk mendokumentasikan aktifitas peserta didik dan aktivitas guru dalam melaksanakan pembelajaran. Tindakan siklus 1 dilaksanakan pada hari selasa tanggal 18 September 2012 dengan alokasi waktu 2 x 40 menit pada jam ke 12, yaitu 07.00-08.30 WIB dalam satu kali pertemuan. Rencana penelitian disusun 
dalam bentuk RPP yang terbagi dalam 3 sesi yang meliputi tahap awal, tahap inti, dan tahap penutup. Tahap awal meliputi eksplorasi diawali dengan membuka pelajaran melalui apersepsi dan menumbuhkan motivasi belajar peserta didik melalui tahap "Tumbuhkan". Kegiatan inti meliputi eksplanasi dengan menerapkan tahap "Alami" yang didalamnya terdapat permainan Snowball Throwing. Tahap "Namai", tahap "Demonstrasi", dan tahap penutup dilakukan dengan mengulang pelajaran yang dilakukan pada tahap "Ulangi" dan tahap "rayakan".

Proses pembelajaran pada tahap awal, guru model mengucapkan salam pembuka yang dilanjutkan dengan meminta peserta didik berdo'a bersama kemudian melakukan presensi kehadiran peserta didik. Pembelajaran diikuti oleh 23 peserta didik karena 1 peserta didik tidak masuk sekolah (tanpa menyertakan surat keterangan tidak masuk sekolah). Observer mengamati proses pembelajaran dengan berdiri di belakang kelas. Observer dilarang membantu peserta didik selama proses pembelajaran berlangsung. Sebelum melaksanakan kegiatan pembelajaran, guru terlebih dulu melakukan apersepsi dengan melakukan tanya jawab dengan peserta didik. Apersepsi ini dapat merangsang kemampuan berfikir dan mengarah ke topik materi yang akan dipelajari yaitu materi metamorfosis.

Proses pembelajaran pada kegiatan inti yang disebut dengan tahap "Alami". Peserta didik dibagi menjadi 5 kelompok secara heterogen. Setiap tiap kelompok beranggotakan 4-5 peserta didik. Guru membagikan lembar kegiatan peserta didik (LKPD) kepada setiap peserta didik serta membagikan hand-out materi metamorfosis dengan tujuan sebagai referensi dan tambahan pengetahuan yang sifatnya dapat memfasilitasi peserta didik untuk memahami dan menemukan suatu konsep yang dipelajari. Diskusi berlangsung selama 20 menit secara berkelompok dengan mengisi LKPD yang telah disediakan. Lembar kegiatan peserta didik (LKPD) ini dirancang untuk menciptakan bentuk kerjasama dan komunikasi antar peserta didik dan mengajak peserta didik berperan aktif dalam pembelajaran. Guru berkeliling kelas memantau dan membantu jalannya diskusi jika ada peserta didik masih belum jelas penjelasan atau bahan diskusinya. Guru dan observer mengarahkan peserta didik untuk menggali dan menemukan jawaban dari setip permasalahan sampai dapat menemukan konsep sendiri. Setelah semua kelompok selesai menjawab permasalahan dalam LKPD mengenai metamorfosis, guru meminta dan memandu peserta didik untuk melakukan Snowball Throwing yaitu dengan memberi tugas kepada peserta didik untuk membuat pertanyaan pada selembar kertas, yang kemudian dibentuk seperti bola (kertas bola soal). Bola kertas yang dibuat dilemparkan dengan kelompok lain. Misalnya bola kelompok 1 dilempar kelompok 2, bola kelompok 2 dilempar kelompok 3, bola kelompok 3 dilempar kelompok 4, bola kelompok 4 dilempar kelompok 5 bola kelompok 5 dilempar kekelompok 1. Setelah masing-masing kelompok mendapat satu bola, guru meminta wakil setiap kelompok untuk menjawab pertanyaan secara bergantian dan membacakan masing-masing soal yang ada pada kertas bola soal tersebut. Setelah proses Snowball Throwing dinyatakan selesai, peserta didik menamai (memberi nama) konsep yang telah dipelajari kemudian guru mempersilahkan salah satu kelompok secara bergantian untuk mempresentasikan hasil diskusi kelompok di depan kelas (tahap "Demonstrasi"). Kemudian kelompok lain dibimbing untuk berdiskusi dalam bentuk memberikan argumentasi dan memberikan masukan ataupun bertanya.

Pada akhir pembelajaran guru menyampaikan kembali tentang konsepkonsep yang kurang jelas dan kesalahankesalahan jawaban peserta didik pada saat presentasi. Guru juga menyampaikan 
kesimpulan dengan tanya jawab untuk mengetahui seberapa jauh peserta didik memahami materi (tahap "Ulangi") serta memberikan reward kepada kelompok yang kinerjanya baik dalam diskusi kelompok maupun pada saat menyampaikan hasil presentasi dan peserta didik yang mampu menjawab pertanyaaan (tahap "Rayakan"). Guru menutup kegiatan pembelajaran dengan mengucapkan salam dan meminta ketua kelas untuk memimpin berdo'a.

Tahap observasi dilakukan untuk mengamati: 1) keterlaksanaan tahapantahapan tindakan pembelajaran kerangka rancangan TANDUR dalam pembelajaran Snowball Throwing dalam kegiatan belajar mengajar pada tiap siklus; 2) indikator penelitian berupa hasil belajar. Indikator hasil belajar meningkat apabila nilai hasil tes yang diperoleh peserta didik mengalami peningkatan dan $\geq$ Standar Kelulusan Minimun (SKM) yaitu 70 serta mencapai ketuntasan klasikal 85\%. Data diperoleh dari hasil observasi aktivitas belajar peserta didik dan aktivitas guru adalah aktivitas belajar peserta didik yang di ukur dari aspek afektif dan psikomotorik, aspek afektif yang meliputi; 1) keberanian; 2) antusias; 3) tenggang rasa; 4) keseriusan; dan 5) keaktifan, sedangkan aspek psikomotorik meliputi; 1) berkomunikasi; 2) menganalisis gambar. Aktivitas guru dalam melaksanakan proses pembelajaran kerangka rancangan TANDUR dalam Snowball Throwing. Berdasarkan data hasil observasi terhadap guru dalam melaksanakan proses pembelajaran kerangka rancangan TANDUR dalam Snowball Throwing pada siklus I baik pada kegiatan awal, inti dan penutup dapat dikatakan bahwa secara umum sudah terlaksana dengan baik meskipun ada beberapa kegiatan yang masih belum dilakukan oleh guru secara maksimal. Kegiatan guru belum berjalan dengan maksimal dimana guru masih kurang dalam membimbing peserta didik menyimpulkan materi. Guru menyimpulkan materi tidak terlalu detail hal ini terjadi karena keterbatasan waktu. Waktu banyak digunakan untuk menjelaskan kerangka rancangan TANDUR dalam Snowball Throwing.

Tes akhir siklus I dilaksanakan pada akhir presentasi. Sesuai dengan indikator peningkatannya, peserta didik dikatakan nilai hasil belajarnya baik atau meningkat apabila nilai tes fomatif yang diperoleh peserta didik $\geq$ Standar Kelulusan Minimal (SKM) yaitu 70.

Berdasarkan data pada Tabel 2, dapat diketahui bahwa dari 24 peserta didik yang mengikuti tes formatif, ada 18 peserta didik yang memperoleh nilai tes formatif di atas SKM $\geq 70$, sementara ada 6 peserta didik yang memperoleh nilai tes formatif di bawah SKM yaitu $<70$. Data pada Tabel 2 selanjutnya dihitung menggunakan rumus ketuntasan klasikal untuk mengetahui persentase ketuntasan. Hasil nilai tes formatif peserta didik pada siklus I yaitu dari 24 peserta didik, ada 18 peserta didik yang tuntas dan 6 peserta didik yang tidak tuntas. Ketuntasan belajar klasikal sebesar 75\% . Berdasarkan kriteria ketuntasan klasikal pada Tabel 2, persentase $75 \%$ berada diantara $70-84 \%$, sehingga kriteria kentuntasan belajar klasikal peserta didik dinyatakan "BAIK".

Penerapan kerangka rancangan TANDUR dalam pembelajaran Snowball Throwing juga diukur dari hasil afektif. Hasil belajar afektif ini mencakup kemampuan menyangkut aspek perasaan dan emosi. Hasil belajar afektif ini merupakan kelanjutan dari hasil belajar kognitif. Penilaian aspek afektif ini diukur melalui 5 (lima) parameter yaitu (1) keberanian, (2) antusias, (3) tenggang rasa, (4) keseriusan, dan (5) keaktifan, kemudian dirata-rata.

Berdasarkan hasil lembar penilaian aspek afektif yang dilihat dari 5 (lima) kemampuan (1) keberanian, (2) antusias, (3) tenggang rasa, (4) keseriusan, dan (5) keaktifan pada siklus I dapat diketahui bahwa masing-masing peserta didik memiliki kemampuan yang berbeda-beda. Hasil penilaian aspek afektif peserta didik 
SMPN 03 Candipuro Lumajang dengan jumlah 24 peserta didik, pada siklus I ratarata adalah 3,38. Hasil belajar psikomotor ini tampak dalam bentuk keterampilan (skill) dan kemampuan bertindak individu. Hasil belajar psikomotor merupakan kelanjutan dari hasil belajar kognitif dan hasil belajar afektif. Penilaian aspek psikomotorik ini diukur melalui 2 (dua) parameter, yaitu (1) aspek berkomunikasi dan (2) menganalisis gambar kemudian dirata-rata. Berdasarkan hasil lembar penilaian aspek psikomotorik pada siklus-I dapat diketahui bahwa masing-masing peserta didik memiliki kemampuan yang berbeda-beda. Hasil penilaian aspek psikomotorik peserta didik SMPN 03 Candipuro Lumajang dengan jumlah 24 peserta didik, pada siklus I rata-rata 3,69. Tahap refleksi dilakukan untuk mengetahui secara menyeluruh tindakan yang telah dilakukan, kemudian dilakukan evaluasi guna menyempurnakan tindakan berikutnya. Berdasarkan hasil observasi selama proses kegiatan pembelajaran pada siklus-1 dapat menjadi bahan refleksi kegiatan pembelajaran untuk perbaikan dan revisi penelitian. Berikut ini adalah observasi observer yang bertugas mengamati keterlaksanaan tahapantahapan kerangka rancangan TANDUR dalam pembelajaran Snowball Throwing dan ketercapaian indikator hasil belajar peserta didik. Setelah dianalisis terdapat kelebihan dan kelemahan yang dapat dijadikan acuan pada perbaikan pada siklus II. Adapun kelebihan dan kekurangan pada siklus I adalah sebagai berikut. 1) Kelebihan siklus I. Pada saat pembelajaran berlangsung peserta didik terlihat antusias dengan penerapan kerangka rancangan TANDUR dalam Snowball Throwing, hal ini tampak dari aktivitas peserta didik dalam kelompok termasuk kriteria baik dalam aktivitas tanggung jawab sosial sehingga perlu ditingkatkan lagi pada siklus berikutnya ditingkatkan pada kriteria sangat baik. Peserta didik terlihat semangat dalam mengerjakan LKPD menggunakan Snowball Throwing. Guru telah menjalankan proses pembelajaran sesuai sintaks kerangka rancangan TANDUR dalam Snowball Throwing.

2) Kelemahan siklus I. Peserta didik masih kesulitan memahami kerangka rancangan TANDUR dalam Snowball Throwing. Masih ada sebagian peserta didik yang belum ikut berpartisipasi dalam membuat pertanyaan maupun dalam diskusi kelompok menjawab pertanyaan. Kelas menjadi ramai pada saat guru memberi kesempatan peserta didik untuk menganailis gambar karena saling melontarkan komentar masingmasing dari gambar yang deprhatikan. Guru kurang optimal dalam menyampaikan materi karena keterbatasan waktu.

Berdasarkan hasil refleksi maka guru, observer beserta guru mata pelajaran Biologi memtuskan untuk memperbaiki kembali kerangka rancangan TANDUR dalam Pembelajaran Snowball Throwing yang akan dilaksanakan pada siklus II. Pelaksanaan siklus II tetap pada Standar Kompetensi (SK) dan Kompetensi Dasar (KD) yang sama, namun materi dan tujuan pembelajarannya yang disampaikan berbeda. Indikator hasil belajar peserta didik belum memenuhi kriteria yang sudah ditentukan.

Siklus II dilaksanakan pada tanggal 25 September 2012. Materi yang disampaikan untuk pertemuan siklus II adalah pokok bahasan Metagenesis.nPerencanaan siklus-II ini dilakukan untuk memperbaiki dan menyempurnakan tindakan-tindakan yang kurang optimal pada saat pelaksanaan siklus-1. Perbaikan-perbaikan tersebut diantaranya dengan menyusun kembali perencanaan yang akan digunakan pada pelaksanaan tindakan siklus-2 meliputi: (1) menyusun Rencana Pelaksanaan Pembelajaran (RPP), (2) memperbaiki dan mempersiapkan lembar observasi keterlaksanaan sintaks, lembar penilaian aktivitas guru dan lembar penilaian aktivitas peserta didik; (3) mempersiapkan LKPD dan kunci jawaban LKPD; (4) mempersiapkan hand out untuk peserta 
didik; (5) mempersiapkan kisi-kisi soal tes; (6) mempersiapkan soal tes sebagai alat ukur hasil belajar peserta didik; (7) serta mempersiapkan kamera untuk mendokumentasikan proses pembelajaran. Observer terdiri dari 3 orang teman peneliti, 2 orang sebagai observer dan 1 orang untuk mendokumentasikan kegitan proses belajar.

Siklus II dilaksanakan pada hari selasa tanggal 25 September 2012 dengan alokasi waktu 2 x 40 menit pada jam ke 12, yaitu 07.00-08.30 WIB yang di hadiri 24 peserta didik. Observer memasuki kelas bersama-sama dengan guru model dan dokumenter. Setiap observer sudah mendapatkan lembar observasi dan lembar penilaian afektif dan penilaian psikomotor, dan lembar penilaian aktivitas guru serta lembar penilaian aktivitas peserta didik Pada tahap awal pembelajaran guru mengucapkan salam pembuka yang dilanjutkan dengan meminta peserta didik berdo'a bersama kemudian melakukan presensi kehadiran peserta didik. Guru menyampaikan indikator pembelajaran yang akan dicapai pada materi metagenesis. Guru memotivasi peserta didik dikegiatan awal pembelajaran dengan beberapa pertanyaan. Guru menyatakan minggu lalu kita sudah mempelajari metamorfosis sekarang kita lanjutkan dengan materi metagenesis. Guru melanjutkan dengan pertanyaan "apa kalian tahu tentang hewan ubu-ubur? Jika kalian tahu, termasuk hewan seperti apa?" Siswa menanggapi pertanyaan dengan beragam jawaban sesuai dengan pengetahuan meraka. Guru menyampaikan tujuan pembelajaran. Pada kegiatan inti yang disebut dengan tahap "Alami" yaitu guru membagi kelompok peserta didik menjadi 5 kelompok yang beranggotakan 4-5 orang peserta didik secara heterogen. Pembagian kelompok selesai guru membagikan hand-out dan LKPD pada masing-masing peserta didik. Guru juga membagikan gambar tentang contoh metagenesis pada hewan ubur-ubur, tumbuhan paku dan lumut. Diskusi berlangsung selama 15 secara berkelompok dengan mengisi LKPD yang telah dibagikan. Diskusi selesai, seperti pertemuan pertama guru meminta tiap kelompok untuk membuat pertanyaan pada selembar kertas dan kemudian dilemparkan kepada kelompok lain. Pertanyaan yang dbuat peserta didik dilemparkan ke kelompok lainnya sambil menyanyikan lagu pop terkenal sampai terdengar abaaba stop dari guru. Ketika terdengar abaaba stop berhenti melempar dan segera membuka kertas dan bergegas mencari jawaban dan berebut mengangkat tangan untuk menjawab pertanyaan. Pewakilan kelompok maju kedepan membacakan pertanyaan dan jawaban. Tahap Snowball throwing selesai peserta didik kembali memberi nama pada konsep yang belum lengkap. Pada tahap "demonstrasi" yaitu prsentasi di depan kelas. Pada saat prsentasi peserta didik aktif mengikuti dengan memberikan tanggapan, bertanya, dan menjawab pertanyaan yang kurang tepat. Pada siklus II aktifitas peserta didik sudah nampak jauh labih bagus daripada siklus I. Peserta didik yang dulunya tidak bertanya menjadi antusias untuk bertanya dan aktif dalam diskusi sehingga terjailah diskusi yang menarik. Di akhir pembelajaran yaitu tahap "ulangi", guru bersama peserta didik menyimpulkan materi yang telah dipelajari dengan cara tanya jawab kepada peserta didik secara acak. Hal ini dilakukan untuk mengetahui penguasaan peserta didik terhadap materi yang telah dipelajari dan didiskusikan. Setelah itu, guru memberikan reward kepada kelompok yang terbaik dalam presentasi (rayakan).

Tahapan observasi dilakukan untuk mengamati: (1) keterlaksanaan tahapantahapan tindakan kerangka rancangan TANDUR dalam model Snowball Throwing pada siklus-2, (2) indikator penelitian berupa hasil belajar peserta didik. Indikator proses pembelajaran dikatakan optimal apabila sintaks yang dilaksanakan sudah terlaksana dengan baik dan juga dilihat dari aktivitas guru dan aktivitas peserta didik yang terus 
meningkat. Sedangkan untuk hasil belajar meningkat apabila nilai hasil tes yang diperoleh peserta didik mengalami peningkatan dan $\geq$ Standar Kelulusan Minimum (SKM) yaitu 70 .

Berdasarkan hasil pengamatan terhadap aktivitas peserta didik selama proses pembelajaran maupun diskusi diperoleh temuan sebagai berikut. a) Kegiatan pendahuluan, guru sudah dapat mengkondisikan peserta didik dengan baik, guru membuka kegiatan belajar mengajar dengan mengucapkan salam dan mengajak peserta didik untuk berdoa. Guru memeriksa kehadiran peserta didik, 1 orang peserta didik datang terlambat. Guru sangat optimal dalam menyampaikan tujuan pembelajaran kemudian dilanjutkan dengan memotivasi peserta didik dengan melakukan apersepsi memberikan pertanyaan-pertanyaan yang dapat menggali kemampuan awal peserta didik, sehingga peserta didik tampak sangat antusias sekali. b) Guru membagi kelompok secara heterogen. Guru sangat optimal dalam membimbing dan memfasilitasi peserta didik bersama kelompoknya untuk merencanakan kerja sama dalam menyelesaikan LKPD dan membuat pertanyaan pada selembar kertas. Pada tahap ini guru juga memberikan kesempatan kepada kelompok untuk mempertanyakan hal yang tidak jelas pada LKPD. c) Guru meminta peserta didik melakukan Snowball Throwing, dengan masing-masing kelompok membuat pertanyaan 2 soal pada selembar kertas yang sudah disediakan oleh guru. Guru memberi pengarahan tentang pertanyaan yang akan dibuat sesuai dengan materi dengan memanggil wakil masing-masing kelompok. d) Melalui diskusi kelompok dan menjawab pertanyaan yang ada pada soal bola kertas yang dibuat oleh peserta didik, maka mereka dapat menemukan konsep materi yang sedang dibahas. e) Tiap kelompok diberi kesempatan mempresentasikan hasil diskusinya, guru memanggil kelompok secara acak dan bergantian ke depan kelas. Guru membimbing peserta didik untuk menanggapi dan bertanya kepada kelompok yang sedang presentasi. f) Mulai dari komentar atau hasil diskusi peserta didik, guru mulai menjelaskan kembali materi yang belum jelas sesuai tujuan yang ingin dicapai, guru kurang optimal melakukan tahapan ini karena guru melakukannya dengan cara tanya jawab yang menimbulkan keramaian di kelas, peserta didik antusias dan berebut untuk menjawab pertanyaan-pertanyaan guru. Dan peserta didik yang memiliki kinerja yang baik maka akan mendapatkan reward dari guru. g. (Kesimpulan), guru sudah optimal dalam memberikan kesimpulan hasil diskusi secara keseluruhan. Guru juga membimbing peserta didik untuk membuat kesimpulan sendiri.

Kegiatan penutup, guru meminta peserta didik untuk mengumpulkan hasil diskusinya ke depan. Peserta didik kembali ke tempat duduk masing-masing dan menyiapkan selembar kertas untuk melakukan tes. Guru memberikan soal tes dan lemabr jawaban yang dikerjakan dalam waktu 10 menit. Guru mengakhiri pertemuan dengan mengucapkan salam dan meninggalkan kelas. Tes akhir siklus II dilaksanakan pada tanggal 25 September 2012 setelah melakukan kegiatan pembelajaran presentasi. Hasil tes belajar peserta didik pada akhir siklus II yaitu dari 24 peserta didik, ada 23 peserta didik yang tuntas dan 1 orang perta didik yang tidak tuntas.

Berdasarkan pada Tabel 2 dapat diketahui bahwa dari 24 peserta didik, 23 peserta didik memperoleh nilai tes formatif $>70$ dan 1 peserta didik memperoleh nilai tes formatif di bawah KKM yaitu $<70$. Sementara ketuntasan belajar klasikal peserta didik sebesar 95,83\% > 70\%. Berdasarkan kriteria ketuntasan belajar klasikal pada tabel 3.2, persentase 95,83\% berada diantara persentase $85 \%-100 \%$ sehingga kriteria kentuntasan belajar klasikal peserta didik dinyatakan "SANGAT BAIK". Selain dilihat dari nilai hasil belajar tes formatif juga diukur dari 
hasil belajar afektif dan psikomotor. Aspek afektif lebih mengarah pada karakter dan daya hidup seseorang. Sedangkan aspek psikomotor dalam proses pengajaran lebih mengorientasikan pada proses tingkah laku atau pelaksanaan. Fungsi aspek psikomotorik ini untuk meneruskan nilai yang terdapat lewat kognitif dan diinternalisasikan melalui afektif sehingga mengorganisasikan dan diaplikasikan dalam bentuk nyata oleh aspek psikomotor. Penilaian aspek afektif ini diukur melalui 5 (lima) parameter yaitu (1) keberanian, (2) antusias, (3) tenggang rasa, (4) keseriusan, dan (5) keaktifan kemudian dirata-rata.

\section{PEMBAHASAN}

Penelitian ini merupakan penelitian tindakan kelas yang bertujuan untuk mengetahui hasil belajar dan ketuntasan hasil belajar peserta didik melalui penerapan kerangka rancangan TANDUR dalam pembelajaran Snowball Throwing. Pelaksanaan kegiatan belajar secara keseluruhan berjalan cukup baik dan lancar. Proses belajar mengajar dengan menggunakan penerapan kerangka rancangan TANDUR dalam Pembelajaran Snowball Throwing berhasil dalam meningkatkan hasil belajar biologi peserta didik dan dapat meningkatkan hasil belajar peserta didik baik secara individual maupun klasikal. Pada penelitian ini, guru menggunakan dua siklus pembelajaran yaitu siklus I dan siklus II.

Menurut Suprijono pembelajaran kooperatif adalah konsep yang lebih luas meliputi semua jenis kerja kelompok termasuk bentuk-bentuk yang lebih dipimpin oleh guru atau diarahka oleh guru. Secara umum pembelajaran kooperatif dianggap lebih diarahkan oleh guru, dimana guru menetapkan tugas dan pertanyaan-pertanyaan serta menyediakan bahan-bahan dan informasi yang dirancang untuk membantu peserta didik menyelesaikan masalah yang dimaksud. Guru biasanya menetapkan bentuk ujian tertentu pada akhir tugas. Model pembelajaran kooperatif dikembangkan untuk mencapai hasil belajar berupa prestasi akademik, toleransi, menerima keragaman, dan pengembangan keterampilan sosial. Model pembelajaran Snowball Throwing adalah model pembelajaran yang penerapannya membuat sebuah pertanyaan yang dituliskan dikertas kemudian diremas menyerupai bentuk bola salju lalu dilemparkan kepada siswa yang lain dan siswa lain yang mendpat bola kertas lalu membuka dan menjawab pertanyaan (Herdian, 2009).

Kerangka rancangan TANDUR terdapat dalam metode Quantum Teaching. Quantum Teaching menganut azas "bawalah dunia mereka kedunia kita dan antarkan dunia kita kedunia mereka", maksudnya seorang guru harus mampu membuat jembatan yang menghubungkan materi yang diajarkan dengan kehidupan peserta didik (DePorter,2008). Pembelajaran Quantum Teaching mengikuti scenario yang dikenal dengan kerangka rancangan yang berorientasi pada pembelajaran kontekstual adalah Tanamkan, Alami, Namai, Demonstrasi, Ulangi, dan Rayakan (kerangka rancangan TANDUR). Melalui penerapan model pembelajaran Snowball Throwing yang didalamnya terdapat kerangka rancangan TANDUR yang bertujuan agar peserta didik lebih mudah memahami suatu materi pelajaran, senang dalam mengikuti kegiatan belajar mengajar, mampu menemukan konsep materi, serta mudah mengingat konsep materi yang diajarkan. Peneliti menyiapkan perangkat-perangkat pembelajaran sebelum melakukan penelitian baik pada siklus I maupun siklus II seperti menyusun silabus dan RPP sesuai dengan indikator ruang lingkup materi pembelajaran yang akan disampaikan kepada peserta didik, menyusun LKPD dan hand out, mempersiapkan kisi-kisi soal tes, mempersiapkan soal tes sebagai alat ukur hasil belajar peserta didik dan rubrik penilaiannya, mempersiapkan media pembelajaran, mempersiapkan lembar observasi penilaian aktivitas guru dan 
lembar penilaian aktivitas peserta didik, serta mempersiapkan kamera untuk mendokumentasikan pelaksanaan penerapan kerangka rancangan TANDUR dalam pembelajaran Snowball Throwing.

Pada siklus I proses pembelajaran dilihat dari nilai hasil belajar pada ranah kognitif, afektif dan psikomotor sudah baik meskipun banyak kekurangankekurangan pada siklusi I. Kekurangan-kekurangan pada siklus I seperti peserta didik yang masih belum berpartisipasi dalam proses pembelajaran, membuat pertanyaan dalam diskusi kelompok yang akan diperbaiki pada siklus II. Pada siklus I proses belajar mengajar masih belum berjalan dengan baik dan lancar sehingga perlu perbaikan pada siklus II, dengan memperbaiki cara mengajar, membuat suasana kelas menjadi nyaman sehingga peserta didik menjadi lebih aktif dalam belajar, dan membagi waktu mengajar dengan sebaik-baiknya seperti yang sudah ditetapkan dalam Rencana Pelaksanaan Pembelajaran (RPP). Pada siklus II pembelajaran sudah berjalan lebih optimal dari pada pembelajaran siklus I. Pada pembelajaran siklus II peserta didik lebih antusias mengikuti proses pembelajaran, membuat pertanyaan dan diskusi kelompok. Hal ini terjadi karena kondisi kelas lebih terkendali akibat perbaikan-perbaikan dari siklus I.

Hasil belajar merupakan puncak dari proses belajar mengajar (Dimyati dan Modjiono, 2009) dan penilaian hasil belajar yang dicapai siswa dalam criteria tertentu. Berikut ini uraian hasil penelitian pada siklus I dan siklus II hasil belajar materi metamorfosis dan metagenesis dengan pembelajaran penerapan kerangka rancangan TANDUR dalam pembelajaran Snowball Throwing. Peningkatan hasil belajar peserta didik dapat diketahui dari hasil penilaian lembar jawaban tes formatif pada setiap akhir siklus. Bentuk soal yang disajikan yaitu berupa soal formatif uraian sebanyak 5 soal yang terdiri dari tingkatan C1, C2,C3, dan C4. Seperti yang telah ditentukan guru mata pelajaran IPA kelas VIIIB SMPN 03 Candipuro Lumajang, bahwa KKM yang harus dicapai peserta didik adalah 70 .

Terdapat peningkatan hasil belajar peserta didik kelas VIII-B pada materi metamorfosis dan metagenesis dari siklus I ke siklus II. Pada siklus I materi metamorfosis dengan perolehan data hasil belajar secara klasikal sebesar $75 \%$ peserta didik (sebanyak 18 peserta didik), sedangkan nilai ketuntasan hasil belajar peserta didik secara klasikal pada siklus II sebesar 95,83\% (sebanyak 23 peserta didik). Hal ini menunjukkan terjadi peningkatan nilai hasil belajar peserta didik secara klasikal sebesar 20,8\% dari siklus I ke siklus II dan sudah dapat dikatakan bahwa ketuntasan belajar peserta didik dapat tercapai.

Hasil belajar pada hakekatnya
adalah perubahan, pemahaman, keterampilan, dan sikap yang biasanya meliputi ranah kognitif, afektif, dan psikomotor (Arikunto, 2006). Ranah kognitif berkaitan dengan hasil belajar intelektual. Aspek kognitif lebih mengarah pada pengetahuan dalam pengajaran kepada peserta didik akan menjadi standar umum untuk melihat kemampuan kognitif seseorang dalam proses pembelajaran. Ranah afektif mencakup kemampuan aspek perasaan dan emosi berkaitan dengan sikap peserta didik dalam menerima terhadap lingkunganya, tanggapan atau respon terhadap lingkungan, penghargaan dalam bentuk ekspresi nilai terhadap sesuatu, megorganisasikan berbagai nilai untuk menemukan pemecahan, serta karakteristik dari nilainilai yang menginternalisasi dalam diri (Krathwol, 1964). Ranah afektif ini memiliki tujuan yang mengacu pada karakter hidup seseorang. Nilai-nilai berkembang secara teratur, sehingga tingkah laku akan menjadi lebih konsisten dan lebih mudah diatur. Tujuan dari kategori ini berhubungan dengan keteraturan pribadi, sosial, dan emosi jiwa. Sedangkan pada ranah psikomotor merupakan hasil belajar psikomotor dalam bentuk keterampilan (skill) dan 
kemampuan bertindak individu. Fungsi aspek psikomotor adalah untuk meneruskan nilai yang terdapat lewat kognitif dan diinternalisasikan lewat afektif sehingga mengorganisasikan dan diaplikasikan dalam bentuk nyata oleh aspek psikomotor ini. Dalam konsteks evaluasi hasil belajar, ketiga ranah tersebut yang harus dijadikan sasaran dalam setiap evaluasi hasil belajar. Menurut Simpson (1996) sasaran kegiatan evaluasi hasil belajar adalah:

1. Apakah peserta didik sudah dapat memahami semua bahan atau materi pelajaran yang telah diberikan pada mereka.

2. Apakah peserta didik sudah dapat menghayatinya.

3. Apakah materi pelajaran yang telah diberikan sudah dapat diamalkan secara kongkret dalam praktek atau alam kehidupan sehari-hari.

Ketiga ranah tersebut menjadi obyek penilaian hasil belajar. Diantara ketiga ranah tersebut ranah kognitiflah yang paling banyak digunakan oleh guru disekolah karena berkaitan dengan kemampuan para peserta didik dalam menguasai isi bahan pengajaran.

Berdasarkan data hasil penelitian pada siklus I dan siklus II pada tabel 2 untuk hasil belajar aspek afektif terus meningkat dari siklus I ke siklus II. Pada siklus I yang diukur dari 5 (lima) parameter yaitu kemampuan keberanian, (2) antusias, (3) tenggang rasa, (4) keseriusan, dan (5) keaktifan pada siklus I dapat diketahui bahwa masingmasing peserta didik memiliki kemampuan yang berbeda-beda. Hasil penilaian aspek afektif peserta didik SMPN 03 Candipuro Lumajang dengan jumlah 24 peserta didik, pada siklus I nilai afektif rata-rata adalah 3,38. Sedangkan pada siklus II adalah 4,10. Pada hasil penilaian belajar aspek psikomotor juga terus meningkat hingga pada siklus II. Pada siklus I hasil belajar aspek psikomotor memiliki rata-rata 3,69. Pada siklus II hasil penilaian aspek psikomotor parameter 1 memiliki rata-rata
4,20 dan parameter 2 memiliki ratarata 3,91. Jumlah ini meningkat dari siklus I kea siklus II. Adapun nilai hasil perbandingan siklus I dan siklus II pada tabel 4.7, parameter 1 siklus 1 rata-rata 3,54 dan siklus II parameter 1 rata-rata 4,20 . Sedangkan pada parameter 2 siklus II jumlah rata-rata 3,58 dan siklus II parameter 2 berjumlah 3,91. Hal ini dikatakan mengalami peningkatan karena pada masing-masing siklus dan parameter sudah dibandingkan jumlah rata-rata kelas dan mengalami peningkatan. Hasil rerata siklus I dan siklus II adalah 3,78.

\section{KESIMPULAN DAN SARAN}

\section{Kesimpulan}

Berdasarkan hasil penelitian dan analisis data yang telah dilakukan, maka dapat disimpulkan bahwa: 1) Penerapan kerangka rancangan TANDUR dalam pembelajaran Snowball Throwing dapat meningkatkan hasil belajar peserta didik. Hal ini dibuktikan dengan hasil belajar siklus II lebih baik dibandingkan siklus I. Pada siklus II peserta didik lebih aktif mengikuti pembelajaran dibandingkan pada siklus I, karena penerapan kerangka rancangan TANDUR dalam pembelajaran Snowball Throwing yang proses pembelajarannya dengan menggunakan metode diskusi dan presentasi, membuat peserta didik lebih berani mengungkapkan pendapat, bertanya, memahami materi, dan lebih aktif dalam diskusi kelompok. Dengan sikap tersebut dapat mempengaruhi hasil belajar peserta didik dengan sikap saling membantu dan saling bekerja sama dengan teman, melatih kecakapan peserta didik, serta menumbuhkan tanggung jawab pada diri peserta didik. 2) Hasil belajar peserta didik melalui penerapan kerangka rancangan TANDUR dalam pembelajaran Snowball Throwing mengalami peningkatan dari siklus I ke siklus II. Hal ini dibuktikan dengan nilai hasil belajar pada siklus II lebih baik dibandingkan siklus I. Jika pada 
siklus I peserta didik yang memperoleh nilai $>$ KKM sebanyak 18 orang $(75 \%)$ sedangkan pada siklus II peserta didik yang memperoleh nilai $>$ KKM sebanyak 23 orang $(95,83 \%)$.

\section{Saran}

Berdasarkan kesimpulan yang di atas, maka peneliti akan menyampaikan beberapa saran yang dapat dijadikan pertimbangan untuk perbaikan proses pembelajaran yang selanjutnya antara lain: 1) Bagi Peneliti Lanjut Penelitian ini dilakukan hanya sebatas kepada peserta didik kelas VIII-B SMPN 03 Candipuro Luamajang, maka peneliti menyarankan agar peneliti lain lebih memperluas subyek yang memiliki prestasi lebih heterogen. 2) Bagi Guru SMP Bidang Studi Biologi. Guru diharapkan bisa menjadikan pembelajaran koopertif model Snowball Throwing yang didalamnya terdapat kerangka rancangan TANDUR sebagai salah satu alternatif dalam proses belajar mengajar. 3) Bagi Siswa SMP 03 Candipuro Lumajang Sebaiknya saat penerapan pembelajaran kooperatif model Snowball Throwing yang didalamnya terdapat kerangka rancangan TANDUR peserta didik terlibat aktif dalam proses pembelajaran yang diberikan oleh guru agar mendapatkan nilai hasil belajar yang maksimal. 4) Bagi Kepala SMP 03 Candipuro Lumajang. Sebagai pertimbangan kebijakan untuk meningkatkan kapasitas guru dalam proses pembelajaran dengan mengikuti pelatihanpelatihan tentang model dan metode pembelajaran dalam upaya meningkatkan proses pembelajaran yang baik.

\section{DAFTAR RUJUKAN}

Anonymous, 2006. Pembelajaran, (Online) http://learning-withme.blogspot.com/ 2006/09/pembelajaran.html Diakses pada tanggal 10 Juni 2012.
Arikunto, Suharsimi. 2006. Prosedur Penelitian Suatu Pendekatan Praktek Edisi Revisi VI. Jakarta: Rieneka Cipta.

Arends, Richard. 2008. Learning To Teach. Yogyakarta: Pustaka Pelajar.

Budiningsih, Asri. 2005. Belajar dan Pembelajaran. Jakarta: Rieneka Cipta.

Chotimah, Husnul dan Dwitasari, Yuyun. 2009. Strategi Pembelajaran untuk Penelitian Tindakan Kelas. Malang : Surya Pena Gemilang.

De Porter, Bobbi, Reardon, Mark \& Signer Sarah. 2008. Quantum Teaching: Mempraktikkan Quantum Teaching Learning di Ruang-ruang Kelas. Bandung:Kaifa.

Dimyati dan Mudjiono. 2009. Belajar dan Pembelajaran.Jakarta:PT.Rineka Cipta .

Efi, 2007. Perbedaan Hasil Belajar Biologi antara Siswa yang diajar melalui Pendekatan Kooperatif Learning Tekhnik Jigsaw dengan STAD, Skripsi Fakultas Ilmu Tarbiyahdan Keguruan. Universitas Islam Negeri Syarif Hidayatulloh.: Jakarta.

Hardjono, R. 2002. Kamus Populer inggris-Indonesia. Jakarta : PT Gramedia Pustaka.

Herdian. 2009. Model Pembelajaran Snowball Throwing. (online) (http://herdy07. wordpress.co, diakses pada tanggal 9 Juni 2012.

Isjoni. 2010. Cooperative Learning Efektivitas Pembelajaran Kelompok. Bandung: Alfabeta.

Kardi, Soeparman \& Mohamad, Nur. 2003. Pengantar pada Pengajaran dan Pengelolaan Kelas. Surabaya: University press.

Kunandar. 2009. Guru Profesional Implementasi Kurikulum Tingkat Satuan Pendidikan (KTSP) dan Sukses dalam Sertifikasi Guru. Jakarta : Rajawali Pers. 
Lie, Anita. 1999. Metode Pembelajaran Gotong Royong. Surabaya: Citra Media.

Mulyasa.2006.Implementasi Kurikulum $2004 . \quad$ Bandung:PT.Remaja Rosdakarya.

Mas'ula, L.2012. Penerapan Pembelajaran Group Investigation (GI) dengan Pendekatan Jelajah Alam Sekitar (JAS) untuk Meningkatkan Kemampuan.

Kerja Ilmiah dan Hasil Belajar Siswa Kelas X7 SMA Negeri 2 Batu pada Materi Ekosistem. Skripsi Tidak Diterbitkan. Malang: Universitas Muhammadiyah Malang.

Rahayu, P, 2009. Penerapan Pembelajaran Kooperatif Model Snowball Throwing untuk Meningkatkan Hasil Belajar Bidang Studi Geografi Materi Semester I SMAN I Patimura Kabupaten Nganjuk. Skripsi Fakultas Matematika dan Ilmu Pengetahuan Alam. Univesrsitas Negri Malang: Malang.

Sudjana, N. 1989. Penilaian Hasil Proses Belajar

Mengajar.Bandung:PT.Remaja Rosdakarya.

Slavin, Robert. E. 1995. Cooperative Learnin Second Edition. Massachusetts: Allyn\&Bacon.

Simpson.1996.(Online)http://infokuh.blogs pot.com/2012/08/pengertianpenilaian-kognitifafektif.html diakses pada tanggal 2 Februari 2013.
Susanto,P. 1999. Strategi Pembelajaran Biologi di Sekolah Menengah. Malang: Universitas Negeri Malang.

Sanjaya. W. 2006. Strategi pembelajaran berorientasi standar proses pendidikan. Jakarta:kencana.

Syah, Muhibbin. 2006. Psikologi Pendidikan dengan Pendekatan Baru. Bandung: PT Remaja Rosdakarya

Sardiman, A, M. 2008. Interaksi dan Motivasi Belajar Mengajar. Jakarta : PT. Raja Grafindo Persada.

Shaffat, Idris. 2009. Optimized Learning Strategy. Jakarta: Prestasi Pustaka.

Suyatno.2009. Menjelajah Pembelajaran Inovatif. Jakarta: Masmedia Buana Pustaka.

Trimo dan rusatiningsih. 2008. Meningkatkan Hasil Belajar IPS melalui Kolaborasi Metode Quatum Teaching dan Snowball Throwing.

http://reserchengines.com/0408trim o.html. Diakses pada tanggal 10 Mei 2010.

Taniredja, Tukiran dkk. 2010. Penelitian Tindakan Kelas.Bandung: Alvabeta cr

Undang-Undang Nomor 20, Tentang Sistem Pendidikan Nasional, Jakarta: CV. Mini Jaya Abadi, 2003.

Winaputra. 2001. Model-model Pembelajaran Inovatif. Jakarta. Universitas Terbuka 
Tabel 2. Data Nilai Hasil Belajar Tes Formatif Siswa Siklus-1 dan Siklus II

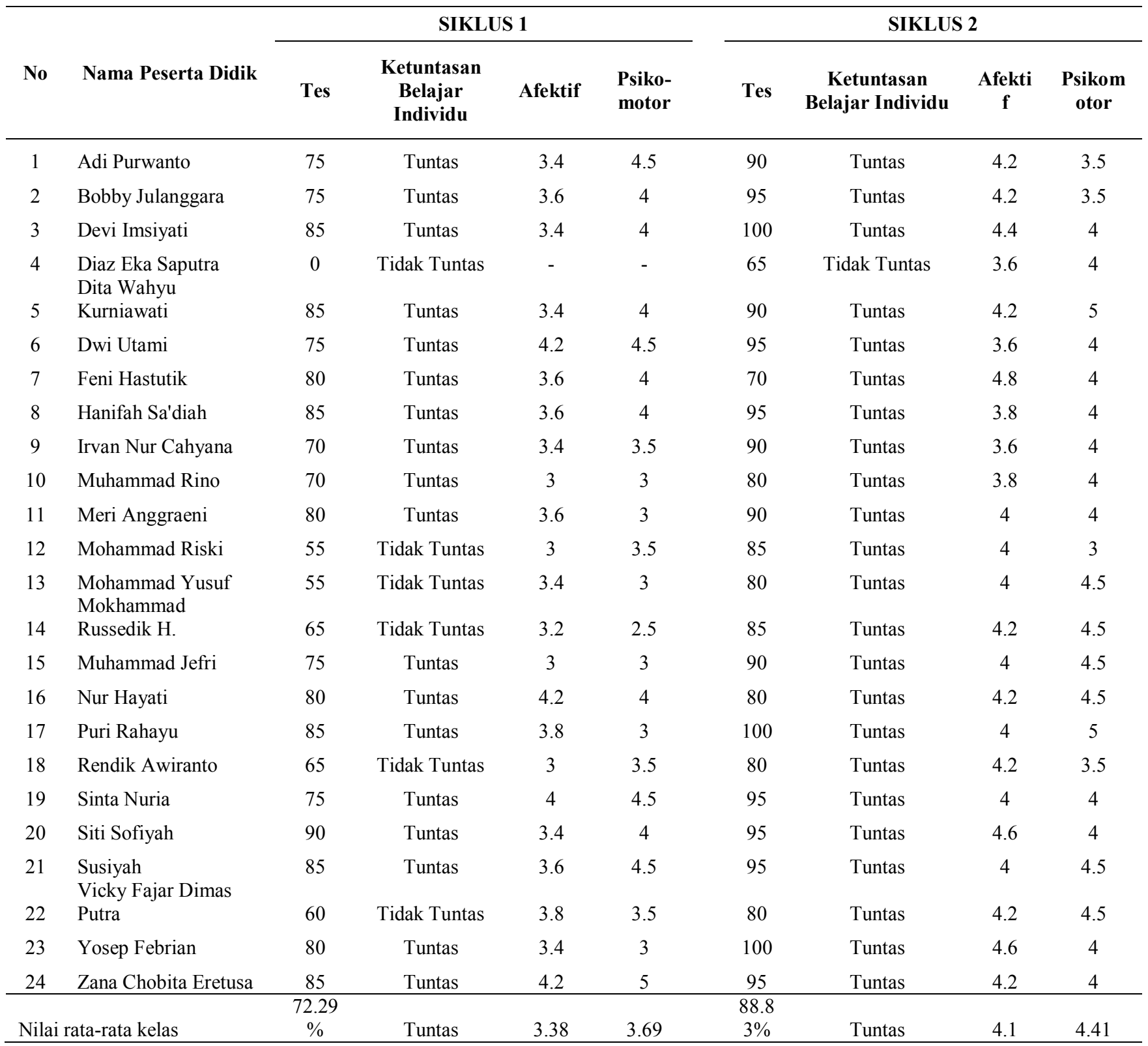

